\title{
UWARUNKOWANIA GEOPOLITYCZNE BAŁKAŃSKIEJ POLITYKI TURCJI W LATACH 20. I 30. XX WIEKU
}

\author{
JĘDRZEJ PASZKIEWICZ
}

\begin{abstract}
Jędrzej Paszkiewicz, Uwarunkowania geopolityczne batkańskiej polityki Turcji w latach 20. i 30. XX wieku (The geopolitical circumstances of Turkish policy in the Balkans during the interwar period (19231939)).

The aim of the article is to show the role of the Balkans in the context of the tasks carried out by the diplomacy of the Turkish Republic in the interwar period. Turkish foreign policy was determined by the position of the state in the three regions - the Mediterranean, the Middle East and the Balkans. These regions were characterized by the fluidity of political relations and heavy dependence on superpowers. In the Balkans, Turkey was an advocate of solutions based on negotiations, not on the arguments of force. On the other hand, the political successes in the Balkans did not substantially strengthen Turkey's attitudes towards other matters concerning the state security. Neither did Turkey increase the Turkish rank in the eyes of superpowers.
\end{abstract}

SŁowA KLUCZOWE: Republika Turecka, Bałkany, Morze Śródziemne, Wielka Brytania, Francja, Włochy KEYWORDS: Republic of Turkey, Balkans, Mediterranean Sea, Great Britain, France, Italy

Balcanica Posnaniensia. Acta et studia, XXI, Poznań 2014, Wydawnictwo Instytutu Historii UAM, pp. 185-198, ISBN 978-83-63047-59-7, ISSN 0239-4278. Polish text with a summary in English.

Jędrzej Paszkiewicz, Uniwersytet im. Adama Mickiewicza w Poznaniu, Instytut Historii, ul. Św. Marcin 78, 61-809 Poznań, paszje@wp.pl.

W historiografii tureckiej, która dotyczy polityki zagranicznej Republiki Tureckiej okresu międzywojennego, państwo to jest najczęściej charakteryzowane jako siła o dużym wpływie na układ stosunków międzynarodowych. Ten stan rzeczy uznaje się za naturalną konsekwencję usytuowania Turcji w trzech strategicznych rejonach ówczesnej polityki międzynarodowej: śródziemnomorskim, bałkańskim i bliskowschod$\operatorname{nim}^{1}$. Z drugiej jednak strony, choćby ze względów ekonomicznych państwo tureckie trudno uznać za siłę polityczną, która w omawianym czasie była w stanie rozwijać

${ }^{1}$ D. Barlas, Statism and diplomacy in Turkey: Economic and foreign policy strategies in an uncertain world, 1929-1939, Leiden 1998, s. 6; idem, Turkish diplomacy in the Balkans and the Mediterranean. Opportunities and limits for middle-power activism in the 1930s, „Journal of Contemporary History”, t. XL, 2005, nr 3, s. 443-444. 
w pełni niezależną aktywność. Pozycja Republiki w całokształcie odniesień międzynarodowych w okresie międzywojennym charakteryzowała się niespójnością między jej potencjałem terytorialnym i demograficznym a realnymi możliwościami w polityce międzynarodowej ${ }^{2}$. Za pośrednictwem działań dyplomatycznych Turcja usiłowała umocnić swoją pozycję na zewnątrz, jak i osłabić niekorzystny wpływ czynników zagranicznych na proces konsolidacji wewnętrznej państwa. Punktem wyjścia do sformułowania celów tureckiej polityki zagranicznej w latach 20 . i 30 . były rezultaty wojny toczonej w latach 1919-1922 między Turcją a siłami Ententy. Obszar państwa tureckiego stał się wówczas przedmiotem ekspansji Wielkiej Brytanii, Francji, Włoch i Grecji, które zmierzały do wytyczenia tam swoich stref wpływów w oparciu o postanowienia traktatu pokojowego z Sèvres (10 VIII 1920 roku). Wojna ta stała się symbolem tureckiego oporu przeciwko quasi kolonialnym aspiracjom mocarstw wobec Anatolii i greckiemu ekspansjonizmowi na wybrzeżu egejskim. Dzięki zwycięstwu militarnemu Turcja obroniła swoją suwerenność, zanegowała ważność układu z Sèvres i utrwaliła swoją obecność polityczno-militarną we wschodniej części Morza Śródziemnego. $Z$ drugiej strony państwo tureckie wychodziło z tego konfliktu uszczuplone terytorialnie, zniszczone i rozdzierane walkami wewnętrznymi. Naczelnym celem władz Republiki, którą proklamowano 29 X 1923 roku, było zapewnienie spokoju na całości terytorium, wzmocnienie rządów republikańskich i przeprowadzenie zmian stabilizujących sytuację społeczno-polityczną oraz ekonomiczną państwa ${ }^{3}$.

Koncepcja tureckiej polityki zagranicznej w omawianym okresie odwoływała się właśnie do konieczności zabezpieczenia szeroko zakrojonych reform wewnętrznych. Ich celem była modernizacja społeczno-polityczna i ekonomiczna państwa oraz społeczeństwa tureckiego. Przywódca republiki Mustafa Kemal Atatürk (1881-1938) reformowanie Republiki Tureckiej identyfikował z westernizacją wszystkich dziedzin życia społeczno-ekonomicznego. Zgodnie z jego założeniami, Turcja, zwrócona ku światu zachodniemu, powinna utożsamiać się z zasadami obowiązującymi wszystkich uczestników ówczesnych stosunków międzynarodowych. M. K. Atatürk podkreślał również antyrewizjonistyczny wymiar tureckiej polityki zagranicznej, która respektowała postanowienia traktatów pokojowych kończących I wojnę światową ${ }^{4}$. Przyjęcie tego stanowiska było możliwe dopiero po unieważnieniu przez Ententę niekorzystnego dla Turcji traktatu pokojowego z Sèvres (10 VIII 1920), podpisanego jeszcze przez wysłanników sułtana Mehmeda VI (1861-1926). M. K. Atatürk jako przywódca tureckiego ruchu narodowego odrzucił warunki tego traktatu, zmierzającego do okrojenia państwa. Prowadził skuteczną walkę z interwencją zewnętrzną, co umożliwiło przyjęcie układu pokojowego w Lozannie (24 VII 1923), satysfakcjonującego z punktu widzenia interesów młodej Republiki ${ }^{5}$. Od tej chwili politycy turec-

${ }^{2}$ A. Akşin, Atatürk'ün Dış Politika İlkeleri ve Diplomasisi, İstanbul 1966, s. 30-31; W. Hale, Turkish foreign policy since 1774, New York 2013, s. 2, 34.

3 A. Jevakhoff, Kemal Atatürk. Droga do nowoczesności, Warszawa 2004, s. 221-223.

${ }^{4}$ Atatürk: his life-revolutions-memories, red. Çetin Tüzüner, s. 58-59.

${ }^{5}$ Zgodnie z postanowieniami traktatu pokojowego w Lozannie, w Europie Turcja odzyskała Trację Wschodnią z Edirne, wyspy egejskie Imbros i Tenedos. W granicach państwa pozostały okolice Izmiru 
cy podkreślali konieczność respektowania zasad prawa międzynarodowego przy rozwiązywaniu spornych kwestii politycznych i terytorialnych. W polityce zagranicznej odnoszono się do słów M. K. Atatürka pokój w domu, pokój na świecie, zaznaczając, że Turcja mogła przetrwać i rozwijać się wyłącznie w warunkach pokoju międzynarodowego ${ }^{6}$.

Traktat pokojowy z Lozanny miał kluczowe znaczenie dla całej polityki zagranicznej Turcji okresu międzywojennego. Na mocy jego postanowień została utwierdzona suwerenność Republiki na arenie międzynarodowej. Na polu bałkańskim umowa z Lozanny stworzyła podstawy pokojowej koegzystencji między tamtejszymi państwami, eliminując większość problemów terytorialnych i ograniczając rezonans kontrowersji dotyczących mniejszości. Z drugiej strony, traktat pozostawił jednak szereg nierozwiązanych kwestii terytorialno-politycznych, dotyczących zwłaszcza przebiegu granic na Bliskim Wschodzie i statusu Cieśnin Czarnomorskich ${ }^{7}$. Sytuacja ta bardzo komplikowała pozycję Turcji, która przez cały okres międzywojenny zabiegała $\mathrm{w}$ relacjach $\mathrm{z}$ mocarstwami o uznanie suwerennych praw w poszczególnych spornych sprawach. O ile z Rosją Radziecką reżim kemalistowski zdołał uzgodnić poszczególne kwestie polityczne jeszcze w trakcie działań wojennych w 1921 roku, tak spór turecko-brytyjski o przyszłość regionu Mosul zdołano rozwiązać dopiero w drugiej połowie lat $20 .{ }^{8}$. Do 1939 roku trwały z kolei rozmowy z Francją dotyczące Syrii. Niepewne były relacje z Włochami, które przejawiały ekspansjonistyczne aspiracje wobec wschodniej części Morza Śródziemnego9.

Ze względu na dynamikę relacji między Republiką Turecką a poszczególnymi mocarstwami, w charakterystyce tureckiej polityki zagranicznej okresu międzywojennego wobec regionu bałkańskiego, można wyróżnić dwie uzupełniające się fazy, obejmujące lata 1923-1932 i 1932-1939. W pierwszym okresie Republika prowadziła działania zmierzające do potwierdzenia lub uszczegółowienia poszczególnych postanowień traktatu lozańskiego drogą dwustronnych negocjacji z państwami sąsiednimi i mocarstwami. Postępująca wówczas stabilizacja międzynarodowa państwa umożliwiła aktywizację jego dyplomacji w regionie bałkańskim. Poprawiając swój

(gr. Smyrna) w zachodniej części Anatolii, okupowane w latach 1918-1922 przez wojska greckie. Zniesiono tzw. przywileje kapitulacyjne dla mocarstw i aliancką kontrolę Cieśnin Czarnomorskich, które jednak miały być zdemilitaryzowane. Turcja straciła okręg Iskenderun (Aleksandretta), który wcielono do francuskiej Syrii i okręg Mosulu na rzecz kontrolowanego przez Brytyjczyków Iraku (ostatecznie w 1926 roku); D. Kołodziejczyk, Turcja, Warszawa 2011. s. 115; W. Hale, op. cit., s. 55-56.

${ }^{6}$ K. Atatürk, Atatürk'ün SöylevIeri, Türk Dil Kurumu Yayınları, Ankara 1968, s. 178); O. Sander, Nationalism and peace. The significance of Atatürks movement, "Turkish yearbook", t. XX, 1980-1981, s. 257; G. Lenczewski, The Middle East in world affairs, Ithaca 1980, s. 121; W. Hale, op. cit., s. 57; A. Jevakhoff, op. cit., s. 266.

7 B. Gökay, A Clash of empires: Turkey between Russian bolshevism and British imperialism (19181923), London 1997, s. 240-249.

8 Idem, Soviet eastern policy and Turkey, 1920-1991, New York 2006, s. 16-23.

9 D. Barlas, Statism and diplomacy, s. 123, 132-139; idem, Friends or foes? Diplomatic relations between Italy and Turkey, 1923-1936, "International Journal Middle East Studies", t. XXXVI, 2004, s. 231252. 
wizerunek na Bałkanach, turecka dyplomacja zmierzała do uzyskania pełnoprawnego statusu w relacjach ogólnoeuropejskich, co z kolei miało wzmocnić jej pozycję w odniesieniu do sporów kolonialnych na Bliskim Wschodzie i wschodniej części Morza Śródziemnego. W 1932 roku Turcja stała się członkiem Ligi Narodów, gdzie była rzecznikiem większego upodmiotowienia mniejszych państw w relacjach zewnętrznych ${ }^{10}$. W kolejnych latach dyplomacja turecka aktywnie uczestniczyła w działaniach na rzecz formowania regionalnych paktów gwarancyjnych na Bałkanach, Morzu Śródziemnym i Bliskim Wschodzie.

Bez wattpienia, w latach 20. geopolityka bałkańska miała dla Turcji drugorzędne znaczenie wobec kontrowersji granicznych rozgrywających się na Bliskim Wschodzie. Dopiero umowa z Wielką Brytanią z 5 czerwca 1926 roku, wieńcząca konflikt o Mosul, stanowiła sygnał, że Republika mogła zwrócić większą uwagę na Europę południowo-wschodnią ${ }^{11}$. W toku zmagań dyplomatycznych z Wielką Brytanią władze tureckie stopniowo normalizowały również stosunki dyplomatyczne z pozostałymi mocarstwami. Dnia 17 XII 1925 roku podpisany został układ o nieagresji i wzajemnej neutralności ze Związkiem Radzieckim, traktowany przez strony jako rozwinięcie umowy z 1921 roku $^{12}$. Pięć miesięcy później, 30 V 1926 roku, przyjęto konwencję o przyjaźni i dobrym sąsiedztwie z Francją, będącą także uzupełnieniem umowy turecko-francuskiej, podpisanej w Ankarze 20 X 1921 roku $^{13}$. Turecki parlament ratyfikował układ z Francją 8 czerwca 1926 roku, w tym samym dniu co porozumienie w sprawie Mosulu, podkreślając w ten sposób, że oba mocarstwa zachodnie miały strategiczne znaczenie dla młodej Republiki. Propaganda kemalistowska akcentowała rolę obu traktatów w cementowaniu politycznej podmiotowości i samodzielności państwa $^{14}$. Z drugiej strony jednak Turcji zależało na utrzymaniu równego dystansu wobec wszystkich mocarstw. Dopiero w maju 1928 roku udało się wynegocjować warunki umowy o przyjaźni, koncyliacji i neutralności z Włochami. Układ ten był owocem akcji dyplomatycznej Włoch, które myślały o stworzeniu sojuszu państw będącego na Bałkanach przeciwwagą dla profrancuskiej Małej Ententy. Kolejnym krokiem ku realizacji tych ambicji było przyjęcie 23 września 1928 roku włosko-greckiego paktu o przyjaźni ${ }^{15}$. Z punktu widzenia Rzymu oba układy miały zapewnić Włochom rolę

${ }^{10}$ W. Hale, op. cit., s. 53-56, 59.

${ }^{11}$ Treaty between the United Kingdom and Iraq and Turkey regarding the settlement of the frontier between Turkey and Iraq together with notes exchanged, "Treaty Series", nr 18 (1927).

12 S. Evans, The slow rapprochement. Britain and Turkey in the age of Kemal Atatürk, 1919-1938, s. 97-101. Turcja i ZSRR utrzymywały dobre stosunki polityczne i gospodarcze do 1936 roku. Choć ZSRR wspierał tureckie stanowisko podczas konferencji w Montreux (1936), strona turecka obawiała się nasilenia radzieckiego nacisku na Cieśniny Czarnomorskie. W Ankarze obawiano się, że zbyt silne więzi z ZSRR doprowadzą do satelityzacji kraju, z drugiej strony w Moskwie krytykowano tureckie próby porozumienia z Wielką Brytanią; D. Barlas, Statism and diplomacy, s. 180.

${ }^{13}$ Balkanski ugovorni odnosi 1876-1996. Dvostrani i višestrani međunarodni ugovori i drugi diplomatski akti o državnim granicama, političkoj $i$ vojnoj saradnji, verskim i etničkim manjinama, Beograd 1998, t. II, s. 222-227; W. Hale, op. cit., s. 58-59.

${ }^{14}$ D. Barlas, Friends or foes, s. 238.

15 Balkanski ugovorni odnosi, t. II, s. 292-295, 299-304. 
mediatora $\mathrm{w}$ rozmowach między tradycyjnymi konkurentami w regionie ${ }^{16}$. Stosunki z Włochami były poważnym wyzwaniem dla tureckiej dyplomacji ze względu na ich ambicje imperialne wobec wschodniej części Morza Śródziemnego. W Ankarze dostrzegano zagrożenie, jakie stanowiły dla tureckich interesów włoskie bazy wojskowe na Dodekanezie, pod koniec lat 20. Turcja przychylnie jednak przyjęła włoską ofertę pośrednictwa w skomplikowanych negocjacjach z Grekami ${ }^{17}$. Działania Włoch w sprawie porozumienia z Grecją M. K. Atatürk uznawał za pożyteczne. Wspierały one plan rozwiązania nabrzmiałego sporu sąsiedzkiego, jednocześnie nie przesądzając o zacieśnieniu współpracy z Rzymem ${ }^{18}$.

Podstawowymi wyzwaniami tureckiej polityki na Bałkanach w latach 20. było potwierdzenie zobowiązań pokojowych i wyjaśnienie kwestii dotyczących praw kulturalnych i własnościowych tureckiej mniejszości w poszczególnych krajach. W tym też duchu Turcja podpisała umowy bilateralne, oddzielnie ze wszystkimi państwami regionu. Najwcześniej, bo w 1925 roku osiagnnięte zostały układy o przyjaźni z Bułgarią (18 X) oraz Królestwem SHS (28 X). W 1929 roku podpisano traktat o neutralności z Bułgarią (6 III), a rok później - z Grecją (10 VI i $30 \mathrm{X})^{19}$. W pierwszej połowie lat 30. XX wieku Turcja była już uznawana jako równoprawny gracz na scenie bałkańskiej. W latach 1932-1933 Republika utwierdziła dobre stosunki z Grecją, Jugosławią i Rumunią, podpisując bilateralne pakty o przyjaźni ${ }^{20}$. W 1934 roku stała się sygnatariuszem Paktu Bałkańskiego, który stanowił podstawę Ententy Bałkańskiej, bloku polityczno-wojskowego czterech państw - Grecji, Jugosławii, Rumunii i Turcji²1.

Na Bałkanach propozycje tureckiej dyplomacji doceniono dopiero wówczas, gdy upewniono się co do braku ekspansjonistycznych i rewizjonistycznych aspiracji wo-

16 W zamierzeniach B. Mussoliniego dopełnieniem porozumienia grecko-tureckiego miały być umowy o podobnym charakterze, zawarte między Turcją a Bułgarią i Węgrami, obliczone na stworzenie bloku polityczno-wojskowego ograniczającego wpływy francuskie G. Carocci, La politica estera dell'Italia fascista (1925-1928), Barri 1969, s. 82.

17 D. Barlas, Turkish diplomacy in the Balkans, s. 451.

18 Documenti diplomatici italiani [dalej: DDI], ser. VII, t. V, dok. nr 18, s. 18.

19 W. Hale, op. cit., s. 60-62. Balkanski ugovorni odnosi, t. II, s. 217, 218, 309-314, 332-340, $344-349$.

${ }^{20}$ Ibidem, s. 373 (Turcja-Grecja; 14 IX 1933), s. 374-378 (Turcja-Rumunia; 17 X 1933), 379-386 (Turcja-Jugosławia (27 XI 1933).

21 Ibidem, s. 387-388; A. Jevakhoff, op. cit., s. 359. Nieobecność Bułgarii w strukturach Paktu Bałkańskiego wiązała się z poważnymi następstwami dla tureckiej polityki w latach 30. Z tureckiego punktu widzenia sytuacja ta sprzyjała nasileniu się włoskiego wpływu na politykę bułgarską. Z powodu Włoch osłabły również więzi sojusznicze z Grecją, która z obawy przed nerwową reakcją Rzymu odmówiła przyjęcia wielostronnych zobowiązań wojskowych w ramach Ententy Bałkańskiej. Z drugiej strony wzrosło znaczenie współpracy turecko-jugosłowiańskiej. Obawy przed bułgarskim rewizjonizmem, wspieranym z Włoch, przesądziły o podjęciu w 1935 roku rozmów dotyczących współdziałania militarnego między Turcją a Jugosławią. Ze wstępnych uzgodnień wynikało, że armia turecka miała trzymać w szachu siły bułgarskie przed zaatakowaniem Jugosławii, obawiającej się agresji ze strony Włoch. W listopadzie 1935 roku w Belgradzie i Bukareszcie doszło do konsultacji z udziałem szefów sztabów generalnych Turcji, Jugosławii i Rumunii. Przyjęto wówczas trójstronne konwencje wojskowe, zakładające wzajemną pomoc w razie ataku militarnego; Ž. Avramovski, Britanci o Kraljevini Jugoslaviji. Godišnji izveštaji Britanskog poslanstva u Beogradu 1921-1938, Zagreb 1995, t. II, s. 312-313. 
bec regionu. W Turcji zdawano sobie sprawę, że na niekorzyść jej politycznej aktywności wpływała silna wśród narodów bałkańskich pamięć o rządach islamskiego mocarstwa, gnębiącego narody chrześcijańskie. Aby pokonać tę przeszkodę, Republika Turecka musiała podważyć wszystkie porównania z Imperium Osmanów i przekonać kraje regionu do swojego koncyliacyjnego stanowiska. Trzeba było uświadomić państwom bałkańskim, że pierwszorzędnym celem nowoczesnej Turcji była likwidacja uprzedzeń krępujących rozwój regionu i wypracowanie wielostronnego porozumienia, wytyczającego szlak ku rozwiązaniom promującym pokój oraz współpracę. Działania przełamujące stereotyp osmańskiego ekspansjonizmu najszybciej zaowocowały wśród elit politycznych ${ }^{22}$. W poszczególnych stolicach bałkańskich patrzono na Turcję z dużymi nadziejami. Stopniowo umacniały się opinie, że współpraca z tym państwem mogła odwrócić niekorzystne trendy w polityce regionalnej. Od zakończenia I wojny światowej we wzajemnych relacjach na Bałkanach panował stan stagnacji, który uniemożliwiał rozwiązanie najważniejszych problemów polityczno-terytorialnych. Poszczególne środowiska intelektualne w Grecji, Jugosławii czy Rumunii wysuwały opinie, że współpraca z Turcją mogła wzmocnić pozycję tzw. sił prowersalskich, walczących o utrzymanie ówczesnego status quo, opartego na postanowieniach traktatów pokojowego oraz otworzyć nowe perspektywy dla regionu, borykającego się poważnymi problemami społeczno-ekonomicznymi. Wrażenie to spotęgowały następstwa wielkiego kryzysu ekonomicznego z lat 1929-1931, gdy okazało się, że zarówno mocarstwa, jak i Liga Narodów były bezradne wobec załamania gospodarczego na świecie. W Jugosławii i Grecji akcentowano, że zbliżenie polityczne z Republiką Turecką było w interesie firm bałkańskich, które przy wsparciu władz i dzięki dogodnym połączeniom komunikacyjnym mogłyby zaistnieć na szerokim obszarze sięgającym aż po Persję, obejmującym Morze Śródziemne i Czarne ${ }^{23}$. Doceniano również to, że Turcja aktywnie i elastycznie poszukiwała sposobu określenia swojej tożsamości geopolitycznej poprzez aktywizację na polu bałkańskim. Nie mogąc zdominować mniejszych państw regionu, rozglądała się za partnerami, z którymi można było ułożyć współpracę bez narażania się mocarstwom.

W Atenach, Belgradzie czy Bukareszcie wskazywano, że państwo tureckie, dystansujące się od ekspansywnych ambicji imperium osmańskiego, mogło powrócić w nowej roli na Bałkany, stając się ważnym elementem stabilizującym ówczesny ład międzynarodowy ${ }^{24}$. Uwadze obserwatorów nie umknął fakt, że turecka dyplomacja mogła nawiązać w tej aktywności do tradycyjnych związków polityczno-kulturowych z regionem. Zdaniem części historyków tureckich, okolicznością ułatwiającą zaangażowanie się Turcji w sprawy Europy południowo-wschodniej było istnienie wspólnej przestrzeni kulturowej, wykreowanej w następstwie wielowiekowej wła-

22 J. Gawroński, Dyplomatyczne wagary, Warszawa 1965, s. 228; D. Barlas, Turkish diplomacy, s. 443; J. Bitzes, The Graeco-Turkish relationship, 1930-1941, „Balkan studies”, t. XXXVIII, 1997, nr 2, s. 308.

23 J. Јовановић, Дипломатска историја Нове Европе, Београд 1938, t. II., s. 473-474.

24 Д. Хаков, Ататюрк, Република Туричя и Балканите, Туричия-Балканите-Европа, w: История и култура. Иследования в чест на професор Дженгиз Хаков, София 2003, s. 26-27. 
dzy imperium osmańskiego nad rozległym obszarem Europy południowej, Bliskiego Wschodu i Afryki północnej. Wiedza i umiejętności pochodzące z czasów osmańskich zostały zaadaptowane przez turecką klasę polityczną na potrzeby nowej polityki, która odwoływała się do wspólnoty celów i interesów państw i narodów Europy południowo-wschodniej ${ }^{25}$. Z drugiej strony należy jednak pamiętać, że z tureckich służb dyplomatycznych zniknęły osoby posiadające wiedzę i umiejętności w zakresie kontaktów politycznych z Bałkanami, co było następstwem czystek personalnych $\mathrm{z}$ lat $20{ }^{26}$. Politykę zagraniczną tworzyły osoby niepowiązane $\mathrm{z}$ wcześniejszym establishmentem, nie zawsze odpowiednio zorientowane w realiach bałkańskich ${ }^{27}$.

Wydarzeniem, które przesądziło o dalszej ewolucji tureckiej polityki ku działaniom na rzecz współpracy regionalnej na Bałkanach było zamknięcie sporów z Grecją, uznawaną za największego wroga Turcji na Bałkanach. Umowa z 30 X 1930 roku pokazała, że Turcja i Grecja były w stanie przezwyciężyć kontrowersje nawet w najbardziej skomplikowanych kwestiach i wpłynąć na zmianę układu sił politycznych w regionie. W latach 20. w Grecji powszechnie pokutował wizerunek Turcji i Turków jako śmiertelnego wroga. Miał on związek z dramatycznymi doświadczeniami z lat 19191922, gdy w związku z wojną grecko-turecką i tuż po jej zakończeniu, do kraju napłynęły rzesze uchodźców, głównie z terytorium Turcji ${ }^{28}$. Normalizacja stosunków dwustronnych była wówczas niemożliwa ze względu na wzajemną nieufność i silne nastroje rewindykacyjne. Dopiero na przełomie lat 20. i 30. XX wieku po obu stronach umocniło się przekonanie, że znacznie więcej można zyskać poprzez współpracę polityczną, a nie konkurencję. Rządzący postanowili odejść od wojowniczej retoryki. Nastawiono się na wygaszenie wszystkich spornych kwestii, nawet za cenę protestów środowisk reprezentujących interesy uchodźców ${ }^{29}$.

Sygnatariusze umowy z 1930 roku podkreślali, że z geopolitycznego punktu widzenia Grecja i Turcja miały zbliżone interesy w regionach bałkańskim i śródziemnomorskim. Za sprawę kluczową uznawano zapewnienie stabilnej pozycji obu państw nad Morzem Egejskim i we wschodniej części Morza Śródziemnego. Korzyści związane z przełamaniem tradycyjnej wrogości grecko-tureckiej były oczywiste także

${ }^{25}$ Gül Akyılmaz, Osmanlı Diplomasi Tarihi ve Teşkilatı, Konya 2000, s. 81.

${ }^{26}$ W następstwie wymiany kadry dyplomatycznej w Turcji w latach 20. XX wieku, na stanowiskach pozostała tylko 1/3 urzędników wcześniej powiązanych ze służbami osmańskimi. Byli to głównie urzędnicy niższego szczebla. Najważniejsze stanowiska objęli kemaliści; G. Harris, Atatürk’s Diplomats and their brief biographies, İstanbul 2010, s. 99-111.

${ }^{27}$ Uwagę obserwatorów zwracał brak obycia tureckich polityków i dyplomatów w wielu kwestiach dotyczących ogólnie pojętej polityki europejskiej. Jak notował w swoich wspomnieniach radca polskiego poselstwa w Turcji Jan Gawroński (1929-1932), tureccy politycy, w tym również zawodowi dyplomaci, niejednokrotnie zwracali się do obcych przedstawicieli, których darzyli szacunkiem, konsultując poszczególne kwestie. Jego zdaniem za szczególnie zaufanego uznawano w Ankarze polskiego posła i ambasadora w Turcji Kazimierza Olszowskiego (1928-1933); J. Gawroński, op. cit., s. 197.

${ }^{28}$ Por. T. Czekalski, Pogrobowcy wielkiej idei. Przemiany spoteczne w Grecji w latach 1923-1940, Kraków 2007.

29 Por. J. Paszkiewicz, Grecja wobec problemów bezpieczeństwa na Bałkanach przed wybuchem II wojny światowej (1936-1940), Poznań 2012, s. 197-198. 
w odniesieniu do Bałkanów. W drugiej połowie lat 20. greckich polityków niepokoiły informacje o francuskich koncepcjach zakładających zbliżenie jugosłowiańsko-tureckie, a także o wspieranych przez dyplomację włoską próbach nawiązania przez Turcję współpracy z Bułgarią. Z kolei w Ankarze z niepokojem patrzono na rozmowy grecko-włoskie, obawiając się, że przełożą się one na współpracę wymierzoną w Turcję ${ }^{30}$.

Umowę z 1930 roku należy traktować jako punkt wyjścia do realizacji planów, zakładających wykreowanie nowego systemu odniesień politycznych, pozwalającego na ograniczenie wpływu mocarstw na politykę bałkańską. Poprzez współpracę dwustronną władze tureckie zamierzały przekonać pozostałe państwa regionu do korzyści związanych z akceptacją tureckiej obecności w polityce bałkańskiej ${ }^{31}$. Co więcej, w Ankarze bardzo entuzjastycznie podchodzono do inicjatyw zakładających stworzenie paktu bezpieczeństwa, obejmującego wszystkie państwa regionu. Marzeniem M. K. Atatürka było przewodniczenie tym działaniom, choć zdawał on sobie również sprawę z ogromu problemów, które trzeba było pokonać na drodze do osiagnięcia tego celu. Zamiarem tureckiej dyplomacji było stworzenie bloku o charakterze neutralnym, który mógłby ograniczyć wpływ mocarstw na politykę w regionie. W Turcji krytykowano politykę Włoch i Francji wobec poszczególnych państw regionu, uważając, że jej głównym celem było pogłębianie istniejących różnic. Negatywnie odnoszono się również do koncepcji o charakterze mediacyjnym lub integracyjnym, podejmowanych przez dyplomacje mocarstw. I tak wspierana przez Francję w latach 20. i 30. idea współpracy jugosłowiańsko-bułgarskiej była uznawana w Turcji, podobnie zresztą jak i w Grecji oraz Rumunii za pomysł antagonizujący relacje na Bałkanach ${ }^{32}$. Krytycznie przyglądano się również włoskiej koncepcji stworzenia, na przełomie drugiej i trzeciej dekady, antyfrancuskiej sieci powiązań politycznych między Grecją, Turcją, Bułgarią i Węgrami, uważając, że jej realizacja zaburzy równowagę sił $w$ regionie i zaowocuje nasileniem ingerencji ze strony mocarstw ${ }^{33}$. Sposobem na wydobycie regionu ze stanu zapaści było, według ministra spraw zagranicznych Turcji Tevfika Rüştü Arasa (1920-1939), przekonanie państw do korzyści płynących ze współpracy regionalnej, niezależnie od ich stosunku do międzynarodowego status quo. W opinii tureckiego polityka, głównymi podmiotami współpracy regionalnej powinny być zarówno Turcja, Grecja, Jugosławia i Rumunia, jak i rewizjonistyczna Bułgaria oraz Albania. T. R. Aras był przekonany, że współpraca polityczna powinna korespondować z działaniami na polu ekonomii, handlu międzynarodowego, oświaty czy kultury ${ }^{34}$. $\mathrm{Z}$ tego względu tureckie delegacje czynnie uczestniczyły w pra-

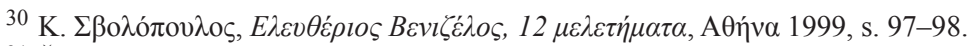

31 Ž. Avramovski, Balkanska Antanta 1934-1940, Beograd 1986, s. 78-84.

32 A. Jevakhoff, op. cit., s. 357.

${ }^{33}$ Archivio storico diplomatico, Roma, Rapporti Politici. Turchia [dalej: ASD], 1933, t. VII, (11 VII 1933). Jak wynika z włoskiej dokumentacji dyplomatycznej, Turcja była zdecydowanie przeciwna wszelkim planom zakładającym tworzenie unii państw słowiańskich na Bałkanach. Aby przeciwdziałać ich realizacji, Turcja gotowa była porozumieć się z państwami rewizjonistycznymi: Włochami, Austrią i Węgrami; ibidem, t. VII/5 (16 IX 1933).

34 Ž. Avramovski, op. cit., s. 78. 
cach ruchu panbałkańskiego, które zaowocowały czterema konferencjami w Atenach, Stambule, Bukareszcie i Salonikach (1930-1933). Istotą tych działań było skupienie uwagi społeczeństw wokół idei współpracy regionalnej ${ }^{35}$.

Bez wątpienia bałkańska polityka Republiki Tureckiej w latach 20. i 30. XX wieku była ściśle powiązana z brakiem zaufania do poczynań Włoch $\mathrm{w}$ akwenie Morza Śródziemnego. W 1923 roku w Turcji krytykowano bierne stanowisko Wielkiej Brytanii i Francji wobec takich incydentów z udziałem włoskim, jak okupacja Korfu czy zajęcie Fiume (Rijeki) ${ }^{36}$. Z rosnącym niepokojem obserwowano wsparcie Włoch dla bułgarskiego i węgierskiego rewizjonizmu oraz rozbudowę baz wojskowych na Dodekanezie. Z tureckiego punktu widzenia aktywność Włoch w Europie południowo -wschodniej była powiązana $\mathrm{z}$ faszystowską ideą budowy drugiego imperium rzymskiego, która godziła w integralność terytorialną Republiki Tureckiej. To mobilizowało Turcję do bardziej zdecydowanych kroków politycznych ${ }^{37}$. Czując się narażona na włoską ekspansję, postanowiła ona wspierać wszystkie projekty tworzenia paktów gwarancyjnych, mogących wzmocnić pozycję mniejszych państw i osłabić naciski z zewnątrz. W zamyśle władz tureckich, traktaty wielostronne, potwierdzające przebieg granic, powinny zaistnieć w trzech regionach - bałkańskim, bliskowschodnim i śródziemnomorskim. Realne szanse na urzeczywistnienie tego planu istniały wyłącznie na Bałkanach ${ }^{38}$. Przede wszystkim w pierwszej połowie lat 30. region ten nie miał pierwszoplanowego znaczenia $\mathrm{w}$ rozgrywkach między mocarstwami a miejscowe państwa w większości posiadały stosunkowo dużą swobodę w działaniach międzynarodowych ${ }^{39}$.

Zaangażowanie się tureckiej dyplomacji w konkretyzację struktur politycznych i wojskowych Ententy Bałkańskiej bardzo skomplikowało stosunki z Włochami. W Rzymie uważano, że Turcja poważnie rozważała współpracę z obozem państw profrancuskich. Włoski ambasador w Ankarze Vincenzo Lojacono podkreślał, że scenariusz zakładający konkretyzację współpracy politycznej w regionie w oparciu o za-

35 Д. Хаков, op. cit., s. 25.

${ }^{36}$ D. Barlas, Turkish diplomacy, s. 444.

${ }^{37}$ Działania Turcji na rzecz powołania Paktu Bałkańskiego nabrały jeszcze większego znaczenia, gdy w marcu 1933 roku Benito Mussolini zaproponował wykreować nowy „koncert mocarstw” o nazwie Pakt Czterech. Jego zdaniem mocarstwa europejskie, Wielka Brytania, Francja, Włochy i Niemcy, powinny współdecydować o sprawach dotyczących pokoju na kontynencie. W Turcji obawiano się, że jeśli dojdzie do tego porozumienia, mocarstwa uzgodnią nowe strefy wpływów zarówno w Europie, jak i na Bliskim Wschodzie, ograniczając możliwość wpływania mniejszych państw na politykę międzynarodową. W dłuższej perspektywie mogło to spowodować satelityzację tych krajów; National Archives, Foreign Office, London [dalej: NA FO], 371/16801, (27 I 1933).

${ }^{38}$ Włochy krytykowały zaangażowanie tureckiej dyplomacji w działania na rzecz tworzenia systemu gwarantującego przebieg granic na Bałkanach. Zdaniem włoskich obserwatorów, porozumienia między Turcją a Grecją, Rumunią i Jugosławią stanowiły punkt wyjścia dla wspólnej ingerencji tych państw w porządek międzynarodowy w regionie. Były wymierzone w Bułgarię i tworzyły prawno-międzynarodowe uzasadnienie dla ewentualnej ingerencji zbrojnej w razie wystapienia kontrowersji terytorialnych; DDI, ser. VII, t. XIV, dok nr 173 (13 IX 1933), s. 185, dok 187 (19 IX 1933), s. 204; Ž. Avramovski, op. cit., s. 123 .

${ }^{39}$ Ibidem, s. 98. 
sadę Bałkany dla narodów bałkańskich groził zachwianiem interesów włoskich na Morzu Śródziemnym. Jego zdaniem, z myślą o swoim bezpieczeństwie władze tureckie przechodziły na pozycje antywłoskie. Korespondowało to z zacieśnianiem współpracy z Jugosławią, którą wcześniej nierzadko krytykowano w Ankarze np. za antybułgarskie nastawienie i nieustępliwość w sprawie macedońskiej. Włoski dyplomata spodziewał się, że oba państwa w krótkim czasie staną się „,czempionami” antywłoskiej polityki na Bałkanach ${ }^{40}$. W niespełna miesiąc po przyjęciu przez Turcję Paktu Bałkańskiego, 18 III 1934 roku Benito Mussolini stwierdził, że celem włoskiego ekspansjonizmu będzie Afryka i tereny azjatyckie. Dodał on, że warunkiem realizacji idei włoskiego mocarstwa kolonialnego była kontrola nad Morzem Śródziemnym ${ }^{41}$. Deklaracje duce nie umknęly uwadze Turcji - państwa lokującego swoje interesy w regionie śródziemnomorskim i na Bliskim Wschodzie. Choć B. Mussolini zapewniał, że nie miał na myśli agresji na terytorium tureckie, w Ankarze nikt nie wątpił, że ekspansja włoska stanowiła poważne zagrożenie dla państwa ${ }^{42}$. Wprawdzie włoski przywódca zapowiadał, że Włochy będą informować Turcję o wszystkich swoich inicjatywach politycznych, dotyczących wschodniej części Morza Śródziemnego, ale relacje z nią postrzegał na zasadzie podległości, a nie partnerstwa. Oczekiwał, że władze tureckie będą honorować włoskie interesy imperialne. W sprawach bałkańskich naciskał, aby Turcja komunikowała się z Włochami bezpośrednio, a nie w imieniu Ententy Bałkańskiej. Gdyby strona turecka przystała na to żądanie, oznaczałoby to zaprzepaszczenie jej dotychczasowych dokonań na polu bałkańskim. Władze w Ankarze podkreślały, że w interesie Republiki było utrzymywanie dobrych stosunków ze wszystkimi państwami na Bałkanach oraz honorowanie wszystkich zobowiązań traktatowych. Turecki premier Mustafa İsmet İnönü (1925-1937) i minister spraw zagranicznych Tevfik Rüştü Aras (1925-1938) byli przekonani, że jednym z celów włoskiej ekspansji było przejęcie kontroli nad jak największą częścią regionu bałkańskiego i jego polityczna „kolonizacja”. Uważali jednak, że utrzymując poprawne relacje z Włochami, Turcja będzie w stanie przekonać stronę włoską przynajmniej do konsultowania poszczególnych działań politycznych w regionie śródziemnomorskim. Z drugiej strony, od początku lat 30 . władze tureckie intensyfikowały działania zmierzające do rozbudowy i umocnienia marynarki wojennej oraz systemu obrony wybrzeża, celem powstrzymania agresji militarnej ze strony Włoch. Oczekiwano również, że ekspansja Włoch w rejonie śródziemnomorskim będzie skuteczniej blokowana przez Francję i Wielką Brytanię ${ }^{43}$.

Turcja była gotowa współuczestniczyć w każdej inicjatywie międzynarodowej, której celem była konsolidacja ładu pokojowego i oddalenie niebezpieczeństwa woj-

${ }^{40}$ ASD.RP, t. 11/1 (26 IV 1934) i 11/1 (26 V 1934).

${ }^{41}$ Il Discorso del Duce alla seconda assemblea quinquennale del regime, 18 marzo 1934, Roma 1934, s. 4; J. Burgwyn, Italian foreign policy in the interwar period 1918-1940, Connecticut 1997, s. $24-27$.

42 M. Michaelis, Italy's Mediterranean strategy in the Mediterranean, 1935-1939, w: Britain and the Middle East in the 1930s, red. M. Cohen, M. Kolinsky, London 1992, s. 47.

${ }^{43}$ ASD.RP 1933/1, t. VII (18 VI 1933). 
ny na Morzu Śródziemnym. Z uwagą przyglądano się działaniom francuskiego ministra spraw zagranicznych Louisa Barthou, który w maju 1934 roku, zaproponował, aby poszerzyć zakres terytorialny Paktu Bałkańskiego, wiążąc go z zobowiązaniami dotyczącymi granic na Morzu Śródziemnym. Turcja uważała, że taki pakt gwarancyjny powinien uwzględniać oprócz mocarstw wszystkie państwa regionu śródziemnomorskie, łącznie z Grecją i Jugosławią. Z zainteresowaniem spoglądano również na działania dyplomacji francuskiej, która w czerwcu 1934 roku prowadziła rozmowy w sprawie stworzenia tzw. Ententy śródziemnomorskiej z udziałem Francji, Jugosławii, Grecji, Turcji i Bułgarii. Oba projekty poniosły jednak porażkę ze względu na niechętne stanowisko Włoch i Wielkiej Brytanii oraz nagłą śmierć L. Barthou, w październiku 1934 roku $^{44}$.

Fiasko wszystkich prób zaaranżowania śródziemnomorskiego paktu gwarancyjnego, mającego w zamyśle tureckim skonsolidować bezpieczeństwo Europy południowo-wschodniej, ukazało słabość dotychczasowych zabiegów, których istotą było utrzymanie dystansu wobec wszystkich mocarstw. W drugiej połowie lat 30. XX wieku kontynuacja tej strategii okazała się niemożliwa, w obliczu zaostrzającej się rywalizacji między wielkimi siłami, a także wobec nasilających się nacisków zewnętrznych na regiony o znaczeniu strategicznym dla Turcji. W odniesieniu do Bałkanów tureccy politycy wyrażali zaniepokojenie wzrastającą aktywnością polityczną i militarną Niemiec. Wkroczenie wojsk niemieckich do Austrii, w marcu 1937 roku, odbierano w Ankarze jako ostrzeżenie, że zmiany terytorialne, dyktowane przez państwa rewizjonistyczne, wkrótce dotkną również obszar bałkańskii ${ }^{45}$. Z niepokojem przyglądano się działaniom dyplomacji niemieckiej w Rumunii, Jugosławii i Bułgarii ${ }^{46}$. W Ankarze umocniło się wówczas przekonanie, że wpływy niemieckie, za którymi stały mocne argumenty o charakterze gospodarczym, bezpowrotnie podważały rolę wielostronnej współpracy regionalnej, jako pomysłu na utrzymanie równowagi w geopolityce bałkańskiej ${ }^{47}$. Pakt Bałkański tracił swoje znaczenie wobec rosnącego uzależnienia poszczególnych państw regionu od nacisków z zewnątrz. Dnia 31 VII 1938 roku członkowie Ententy Bałkańskiej, powodowani nadzieją, że Bułgaria była skłonna porzucić politykę rewizjonistyczną, zgodzili się na likwidację zdemilitaryzowanych stref przy granicy bułgarsko-greckiej i bułgarsko-tureckiej. Co więcej, zaakceptowali oni unieważnienie ograniczeń dotyczących uzbro-

${ }^{44}$ L. Spasov, Les projets d'un pacte mediterraneen et l'Entente Balkanique 1934-1937, ,Etudes Balkaniques", nr 2, 1987, s. 7.

${ }^{45}$ Chłodne stanowisko Turcji wobec Niemiec w drugiej połowie lat 30. XX wieku nie korespondowało z dynamicznym rozwojem kontaktów handlowych między obu państwami. W 1936 roku wartość eksportu z Turcji do Niemiec stanowiła aż $52 \%$ całego eksportu tureckiego, a importu z Niemiec do Turcji $45 \%$. W tym samym czasie udział tureckiego eksportu do Wielkiej Brytanii szacowano na 5\% (importu $7 \%$ ) a do Francji tylko na 3\% (importu na 3\%), D. Barlas, Statism and Diplomacy, s. 153-154; O. Silier, The place of Anglo-Turkish relations in the foreign policy of the Turkish Republic (1923-1939), "The Turkish Yearbook", t. XI, 1971, s. 98.

${ }^{46}$ W. Hale, op. cit., s. 64

${ }^{47}$ Ibidem, s. 65. 
jenia armii bułgarskiej, nałożonych przez traktat pokojowy z Neuilly-sur-Seine (27 XI 1919) ${ }^{48}$. Przyjęcie tej umowy nastapiło pod presją Wielkiej Brytanii, która wierzyła, że Bułgarię można było skłonić do współpracy przeciwko Niemcom i Włochom. Turcja początkowo protestowała przeciwko temu rozwiązaniu, ale ostatecznie przyjęła je jako „fakt dokonany”49.

Po śmierci M. K. Atatürka, 10 XI 1938 roku, naczelną zasadą liderów państwa tureckiego było osłabienie nacisków ze strony Niemiec i Włoch poprzez rozwinięcie współpracy polityczno-wojskowej z Francją i Wielką Brytanią oraz umocnienie dobrych stosunków ze Związkiem Radzieckim. İ. İnönü żywił wówczas przekonanie, że ZSRR doceni rolę Turcji jako obrońcy radzieckich interesów w Europie południowo-wschodniej, blokowanych przez ekspansję niemiecką. Próby zainteresowania ZSRR tureckimi inicjatywami w sprawie wielostronnego paktu gwarancyjnego, podejmowane w latach 1936-1938, tuż po konferencji w Montreaux, spełzły jednak na niczym ze względu na zacieśniającą się współpracę radziecko-niemiecką w sprawach wschodnioeuropejskich oraz wzrost rywalizacji między ZSRR a mocarstwami zachodnimi ${ }^{50}$. Co więcej, aż do początku 1939 roku Turcja nie była w stanie przekonać Wielkiej Brytanii i Francji, aby porzuciły pasywne stanowisko wobec bezpieczeństwa Europy południowo-wschodniej. Aż do kwietnia 1939 roku tureckie propozycje zaaranżowania wielostronnych traktatów o nieagresji, obejmujących swoim zasięgiem państwa bałkańskie, środkowo- i wschodnioeuropejskie, w tym również Polskę, napotkały na niechęć w Londynie i Paryżu ${ }^{51}$. Wezwania do współpracy zyskały pozytywny odzew ze strony mocarstw zachodnich dopiero w następstwie wkroczenia wojsk włoskich do Albanii (7 IV 1939) ${ }^{52}$. Dnia 12 IV brytyjska dyplomacja przedstawiła Turcji projekt traktatu z wzajemnymi gwarancjami bezpieczeństwa, następnego dnia wystosowała je również pod adresem Grecji i Rumunii ${ }^{53}$. Wspólną deklarację brytyjsko-turecką w tej sprawie przyjęto $12 \mathrm{~V}$, na dziesięć dni przed podpisaniem tzw. paktu stalowego między Niemcami a Włochami. Wielka Brytania i Turcja zapowiedziały, że będą wspierać swoje działania polityczno-militarne w rejonie śródziemnomorskim, gdy któraś strona umowy zostanie zaatakowana przez państwo trze-

48 DDI, ser. VIII, t. IX, dok. nr 363 (2 VIII 1938), s. 490, dok. nr 366 (3 VIII 1938), s. 493. Traktat w Salonikach podpisał w imieniu sojuszników z Ententy Bałkańskiej ówczesny szef Rady sojuszu Ioannis Metaxas. Strony zadeklarowały, że będą prowadzić politykę pokojową, ale Bułgaria nie została zobowiązana do porzucenia żądań rewizji granic. Porozumienie brytyjsko-bułgarskie w sprawie uchylenia klauzul ograniczających rozwój bułgarskich sił zbrojnych, lądowych, morskich i powietrznych zostało podpisane 12 VIII i 24 IX 1938 roku; Balkanski ugovorni odnosi, t. II, s. 418-420.

49 DDI, ser. VII, t. IX, dok. nr 368 (3 VIII 1938), s. 499-501.

${ }^{50}$ W. Hale, op. cit., s. 63, 65

51 Z obojętnością Wielkiej Brytanii spotkała się np. propozycja R. T. Arasa, wówczas tureckiego ambasadora w Londynie, zgłoszona w marcu 1939 roku, aby doprowadzić do zawarcia wielostronnej umowy o nieagresji między ZSRR, Polską, Rumunią i Turcją. Dyplomata sugerował ponadto, że Turcja, Jugosławia i Grecja mogłyby przystąpić do umowy brytyjsko-włoskiej z 1938 roku, przewidującej koordynowanie działań w rejonie śródziemnomorskim; ibidem, s. 66.

52 Balkanski ugovorni odnosi, t. II, s. 420-421.

53 J. Bitzes, The Graeco-Turkish relationship, s. 312-313; W. Hale, op.cit., s. 66. 
cie. Wstępne porozumienie w sprawie wspólnych gwarancji bezpieczeństwa ze strony Wielkiej Brytanii i Francji osiagnięto na początku września 1939 roku, a zatem już po wybuchu II wojny światowej, ale podpisanie definitywnego traktatu odłożono do chwili wynegocjowania przez Turcję podobnego układu z ZSRR. Rozmowy w tej sprawie zakończyły się niepowodzeniem ${ }^{54}$. Fiasko poniosły również tureckie próby stworzenia neutralnego wobec wojny bloku państw bałkańskich. Propozycję tę odrzucono już na etapie konsultacji jako nieprzystającą do ówczesnej sytuacji, zdominowanej przez rywalizację mocarstw ${ }^{55}$. Ostateczny dokument między Wielką Brytanią, Francją a Turcją został przyjęty 19 X 1939 roku. Wkrótce podobne gwarancje bezpieczeństwa otrzymały Grecja i Rumunia ${ }^{56}$.

Polityka turecka $\mathrm{w}$ głównych swoich założeniach pokrywała się $\mathrm{z}$ dążeniami do utrzymania poprawnych stosunków ze wszystkimi najważniejszymi siłami. Projekty wspierające pokojową stabilizację w Europie południowo-wschodniej korespondowały z zamiarami zrównoważenia relacji ze wszystkimi mocarstwami zainteresowanymi tym regionem. Bałkańska przestrzeń geopolityczna była przez strategów tureckich traktowana jako integralnie powiązana z obszarem śródziemnomorskim i bliskowschodnim. Osiagnięcia dyplomatyczne w zakresie umacniania ładu wersalskiego na Bałkanach miały stanowić punkt wyjścia do podobnych działań w znacznie bardziej złożonych realiach geopolitycznych Morza Śródziemnego. O ile jednak w przypadku bałkańskim Turcja mogła kreować nowe rozwiązania polityczne, to w polityce śródziemnomorskiej i na Bliskim Wschodzie nie było na to miejsca ze względu na wzmożoną rywalizację między mocarstwami.

Bez wątpienia Bałkany zajmowały szczególne miejsce w strategii Turcji, jako państwa aspirującego do odgrywania aktywnej roli w polityce europejskiej. Tureckie inicjatywy polityczne spotkały się tam z pozytywnym odzewem, współtworząc warunki umacniające bezpieczeństwo Republiki. Turecka dyplomacja nie przyczyniła się do rozwiązania żadnego spornego problemu w regionie, ale wykazała się elastycznością, nastawieniem kompromisowym i negocjacyjnym, a także cieszyła się zaufaniem w stolicach bałkańskich. Była promotorem idei regionalnego bezpieczeństwa międzynarodowego i rzecznikiem rozwiązań opartych na negocjacjach, a nie argumentach siłowych. Niestety sukcesy odnotowane na polu bałkańskim nie wpłynęły na wzmocnienie pozycji Turcji wobec innych ważkich kwestii, dotyczących bezpieczeństwa Republiki. Nie przełożyły się na wzrost tureckich notowań w oczach mocarstw i nie zapobiegły uzależnieniu się tego państwa od nacisków zewnętrznych.

54 DDI, ser. IX, t. I, dok. nr 359 (21 IX 1939), s. 220, dok. nr 614 (5 X 1939), s. 379, dok. nr 773 (17 X 1939), s. 487, dok. nr 789 (18 X 1939), s. 496; W. Hale, op. cit., s. 68-69.

${ }^{55}$ DDI, ser. IX, t. I, dok. nr 560 (2 X 1939), s. 444.

56 Ibidem, dok. nr 823 (20 X 1939), s. 520. Dnia 19 X Wielka Brytania i Francja zobowiązały się również do pomocy w zaopatrzeniu armii tureckiej; Balkanski ugovorni odnosi, s. 429-434; W. Hale, op. cit., s. 69; D. Barlas, Statism and diplomacy, s. 186-197; L. Zhivkova, Anglo-Turkish relations, 19331939, London 1976, s. 114. 


\title{
THE GEOPOLITICAL CIRCUMSTANCES OF THE TURKISH POLICY IN THE BALKANS IN THE INTERWAR PERIOD (1923-1939)
}

\author{
JĘDRZEJ PASZKIEWICZ
}

\section{Summary}

The aim of the article is to show the role of the Balkans in the context of the tasks carried out by the diplomacy of the Turkish Republic in the interwar period. Turkish foreign policy was determined by the position of the state in the three regions - the Mediterranean, the Middle East and the Balkans. These regions were characterized by the fluidity of political relations and heavy dependence on superpowers. Surviving in these conditions required a great flexibility of political actions on the part of the Turkish state. The activity of the Turkish diplomacy in the Balkans should be divided into two phases covering the years 1923-1932 and 1932-1939. In the first period, Turkey focused on resolving different territorial and political disputes and stabilizing bilateral relations. In the second phase, Turkey intensified its attempts to strengthen peace and order. It became a proponent of the greater empowerment of smaller countries in regional relations and of the reduction of the influence of superpowers. Moreover, Turkey initiated and supported the efforts for or regional guarantee pacts which apart from the Balkans extended also to the Mediterranean and the Middle East. Many Turkish diplomatic initiatives met with a positive reaction in the Balkans. Turkey was an advocate of solutions based on negotiations, not on the arguments of force. On the other hand, the political successes in the Balkans did not substantially strengthen its position in other matters concerning Turkish security. Neither did Turkey increase the Turkish rank in the eyes of superpowers. 